\title{
ANTRITRUST TREATMENT OF BUNDLED DisCOUNTS AND REBATES IN THE UNITED STATES AND EUROPE: MAPPING UNCHARTED TERRITORIES
}

\author{
Hui Hua
}

\begin{abstract}
Bundled discounting is one of the most unsettled areas of competition law. The economic and legal thinking behind this particular type of unilateral practices is in a constant state of flux. Advances in economics have illustrated a strong theoretical case that, even though such practice generally does not raise antitrust concerns, bundled discounting by a monopolist may nonetheless harm competition in some circumstances. What troubles law makers and enforcement authorities, is how best to categorise, prevent, detect, control and regulate such harm. This article attempts to clarify as well as organise coherently some of the important components of the main arguments presented by antitrust experts in this area. It surveys the recently proposed antitrust liability standards on how to distinguish procompetitive and anticompetitive bundling practices, and explores whether appropriate liability standards for analysing bundled discounts by dominant players are now more discernible.
\end{abstract}

\section{A. INTRODUCTION}

'Bundled discounting is the practice of offering discounts or rebates contingent upon a buyer's purchase of two or more different products. ${ }^{1}$ It is one of the most unsettled areas of competition law. One of the main reasons for this is that there has been very little case law either in the US or EU tackling this specific subject. The explosion of academic discourse has also been relatively recent. ${ }^{2}$ Of course, the multifaceted nature of the issue itself has contributed to the complexity of the legal and economic analysis in this area, as I will attempt to demonstrate throughout this paper.

The economic and legal thinking behind this particular type of unilateral practices is in a constant state of flux. On one hand, the

\footnotetext{
${ }^{1}$ U.S. Department of Justice, 'Competition and Monopoly: Single Firm Conduct under Section 2 of the Sherman Act' (2008), Chapter 6: Bundled Discounts and Single-Product Loyalty Discounts, $<$ http://www.justice.gov/atr/public/reports/236681.htm> accessed on 2 July 2012. ${ }^{2}$ R H Pate, 'The Common Law Approach and Improving Standards for Analysing Single Firm Conduct' (Thirtieth Annual Conference on International Antitrust Law and Policy, Fordham Corporate Law Institute, 23 October 2003) $<$ http://www.usdoj.gov/atr/public/speeches/202724.htm > accessed on 2 July 2012.
} 
ubiquitous nature of such arrangements provides evidentiary support for the argument that they are usually based on good efficiency grounds and benefit consumers. ${ }^{3}$ On the other hand, advances in economics have illustrated a strong theoretical case that, even though such practice generally does not raise antitrust concerns, bundled discounting by a monopolist may nonetheless harm competition in some circumstances. ${ }^{4}$ What troubles law makers and enforcement authorities, is how best to categorise, prevent, detect, control and regulate such harm.

This paper's contribution is an attempt to clarify as well as organise coherently some of the important components of the main arguments presented by antitrust experts in this area. It surveys the recently proposed antitrust liability standards on how to distinguish procompetitive and anticompetitive bundling practices, and explores whether appropriate liability standards for analysing bundled discounts by dominant players are now more discernible.

I begin this article by offering some clarifications on current terminology on bundling in general, and bundled discounts in particular in part B. I focus on the variety of ways that we can sub-categorise this particular type of unilateral practices (by thresholds, by scope of application and by the products or set of products to which they apply) ${ }^{5}$ and why certain sub-groups, such as individualised/loyalty discounts, cause more antitrust concerns than others.

After that, I move onto the theoretical discussions of the economic explanations behind bundled discounting practices. Part $\mathrm{C}$ exposes a certain irrationality in the underlying assumptions that many hold and cautions against prejudging as a result. The potential efficiencies and strategic reasons for bundled discounting are also laid out.

Part D further qualifies the theoretical complexity of this topic. My aim is to effectively demonstrate that a total lack of unity on the economic theories of harm in this area is a major obstacle against designing a set of

\footnotetext{
${ }^{3}$ See Herbert Hovenkamp, Federal Antitrust Policy: The Law of Competition and its Practice ( $3^{\text {rd }}$ edn, Thomson-West 2005).

${ }^{4}$ See e.g. Bruce H. Kobayashi, 'Does Economics Provide a Reliable Guide to Regulating Commodity Bundling by Firms? A Survey of Economic Literature' (2005) 1 Journal of Competition Law and Economics 707.

${ }^{5}$ Damien Geradin, 'A Proposed Test for Separating Pro-competitive Conditional Rebates form Anti-competitive Ones' (2009) 32 World Competition 41, 44.
} 
effective and coherent liability standards for bundled discounts. I then examine how this problem reveals itself in practice through a general survey of the legal landscape in part E. This covers both the case law and the latest official reports by the relevant competition authorities in the US and the EU.

In part F, I scrutinise the defects of the currently available tests on bundled discounts by a close examination of the substantive categories of the issue, including the desirability of 'safe harbours' and an efficiency filter, as well as the predation and tying analogies of bundled discounts.

This is followed by part $\mathrm{G}$ in which I carry out a more contextual study of the issues. Here I argue that law makers should bear in mind, (1) the potential danger of chilling legitimate price-cutting by punishing monopolists' actions on purely speculative grounds; (2) the fundamental limitations of economics as a tool to measure the competitive effects of such unilateral actions; (3) the error costs and trade-offs when choosing the right analytical framework; and (4) the different purposes that competition law regimes are designed to serve in US and Europe, and how they inevitably affect the nature of the tests that courts and competition authorities eventually choose to adopt. I suggest that a robust and optimal legal test separating the procompetitive and anticompetitive types of bundled discounting practices should be based on a thorough understanding of the broader picture and the crucial factors at play. This entails taking a step back and considering the contextual issues.

Finally, I conclude this paper by commenting on some recent propositions by leading scholars on the topic of bundled discounts, as well as joining the segments of my analysis to group them together coherently under one single observation.

It is important, however, to note two important limitations to the scope of this paper. First, I do not attempt to judge in an overly precise manner the correctness of each individual economic theory mentioned in this paper. My purpose is merely to illustrate the extent of theoretical confusion surrounding bundled discounts and to demonstrate how it has reflected negatively on the legal rules in this area. Secondy, although the analysis throughout this paper does entail a comparative perspective on the antitrust treatment of bundled discounts in the United States and Europe, this should not primarily be viewed as an in-depth study on whether the laws are converging or diverging in this area. The 
comparative aspect merely helps in the effort to build a better understanding of the major sources of controversy regarding this particular type of unilateral practice.

\section{B. ISSUES WITH TERMINOLOGY: BUNDLING, TYING AND BUNDLED Discounts}

The terminology in the literature must first be clearly defined as differing sources denote differing meanings when referring to certain terms. Loosely speaking, 'bundling' is the sale of collections of goods as packages. The composites of such collections may vary, as well as the conditions that apply to the availability of special pricing for these bundles.

Bundled discounting practices can take a variety of forms. In the simplest case, there can be fixed ratio bundles where buying products $\mathrm{A}$ and $\mathrm{B}$ as a package would result in a discount compared with buying them 'à-la-carte', nevertheless, both the bundle and the stand-along versions of the individual goods are available. This is called 'mixed bundling'. 'Pure bundling' occurs when it is only possible to buy the two products together. ${ }^{7}$

A 'lump sum discount' is a special case of an 'all units discount'. ${ }^{8}$ There are also 'standardised quantity discounts' to be triggered once the buyer passes a pre-determined quantity threshold. These can be further divided into the following sub-groups: (1) discounts for the incremental units above the threshold; (2) discounts for all units once triggered by the buyer's crossing of the threshold, usually called 'first unit discounts' or 'retroactive discounts'. ${ }^{9}$ Such quantity discounts, however, do not always have to be standard, but can be individualised to apply differently to different buyers. This would then turn into a type of loyalty

\footnotetext{
${ }^{6}$ Stan J. Liebowitz and Stephen E. Margolis, 'Bundles of Joy: the Ubiquity and Efficiency of Bundles in New Technology Markets' (2008) 5 Journal of Competition Law and Economics 1.

${ }^{7}$ Richard Whish and David Bailey, Competition Law (7 $7^{\text {th }}$ edn. OUP 2012) 689-90.

${ }^{8}$ Nicholas Economides, 'Tying, Bundling, and Loyalty/Requirement Rebates' in Einer Elhauge (ed), Research Handbook in the Economics of Antitrust Law (Edward Elgar 2012).

9 ibid 132-3.
} 
agreement. ${ }^{10}$ Another way that loyalty agreements can work is where the buyer agrees to buy a certain share of its needs of the two products $\mathrm{A}$ and $B$ (in the simplest scenario) from the same seller, on a generally more preferable terms than otherwise. ${ }^{11}$

Economides asserts that we should be more concerned about individualised loyalty/requirement discounts than about standardised discounts. The reason given is that individualised discounts can be tailored to exclude competitors. ${ }^{12}$ This also reflects the stance of the European Commission, whose Guidance makes it clear that standardised discounts are treated more leniently. ${ }^{13}$ It has been put forward that in the case of standardised discounts the threshold may be too low for larger customers to have a loyalty enhancing effect. On the other hand, an individualised threshold allows the dominant supplier to set the threshold at such a level that it is difficult for customers to switch supplier, thus creating maximum loyalty enhancing effects and helps to extract even more surplus for the monopolist. ${ }^{14}$

A volume discount tends to be more restrictive for the reason that it will not require that the buyer makes fewer purchases from the competitor(s) and thus still leaves open for it to buy from rivals at competitive prices. ${ }^{15}$ Conditional discounts that apply to all units are in general more problematic than those that apply only to incremental units. The reason given is that such type of discounts typically has an exclusionary purpose. ${ }^{16}$

\footnotetext{
${ }^{10}$ ibid.

11 ibid 121-2.

12 ibid 132-3.

${ }^{13}$ European Commission, 'Guidance on the Commission's Enforcement Priorities in Applying Article 82 of the EC Treaty to Abusive Exclusionary Conduct by Dominant Undertakings' COM (2009) 864 available at http:/ec.europa.eu/competition/antitrust/art82/index.html accessed on 2 July 2012. Note that all references to art. 82 in the Guidance should be understood as references to the current art 102 of the Treaty on the Function of the European Union (as renamed by the Treaty of Lisbon, which entered into force on 1 December 2009).

14 ibid para. 45.

${ }^{15}$ Einer Elhauge, 'Tying, Bundled Discounts, and the Death of the Single Monopoly Profit Theory'(2009) 123 Harvard Law Review 397, 451-3, 456.

${ }^{16}$ Economides (n 8) 132-4.
} 
Closely related to the idea of bundling and bundled discounts is the practice of 'tying' or 'tie-in sale', which refer to the types of arrangements whereby a buyer's access to the tying good is conditioned on him consenting to purchase a certain amount of one or more tied goods from the seller. ${ }^{17}$ This can include, amongst others, contractual tying, where the tie is the result of a specific stipulation, or technical tying, where the tied product is physically integrated into the tying product. ${ }^{18}$ The focus of this essay is on the subject of bundled discounts in its variety of forms. However, I will also discuss the issue regarding tying and bundling in general where relevant.

\section{Potential Procompetitive Benefits}

\section{Underlying Assumptions}

One of the first problems with determining a proper legal test for bundled discounts is that there are some underlying assumptions about such practices which, if not dealt with correctly, could potentially make our subsequent analysis less rigorous.

Firstly, the word 'discount' has tricked many into thinking that such offerings are 'presumptively procompetitive' because they must lower prices to buyers. Such an assumption can be highly misleading. ${ }^{19}$ In fact, all it means is that buyers who comply with the bundle will be charged less than those who do not. ${ }^{20}$ It would be incorrect to automatically assume that that the noncompliant prices equal the but-for prices (the prices that would have prevailed 'but for' the bundling). ${ }^{21}$ Such offerings, therefore, need not reflect true discounts at all. This is mainly due to the fundamental fact that the monopolist can set the noncompliant prices at whatever level it wishes. As Elhauge further exposes, if the noncompliant

\footnotetext{
${ }^{17}$ Liebowitz and Margolis (n 6) 3.

${ }^{18}$ Whish and Bailey (n 7) 689.

${ }^{19}$ Daniel A. Crane, 'Mixed Bundling, Profit Sacrifice, and Consumer Welfare' (2006)

55 Emory LJ 423, 465; Thomas A. Lambert, 'Evaluating Bundled Discounts' (2005)

89 Minn. L. Rev. 1688, 1726.

${ }^{20}$ Einer Elhauge (n 15) 450.

${ }^{21}$ ibid.
} 
prices charged exceeds the but-for levels, then the bundling practice is, in fact, penalising the buyers who refuse the bundle. ${ }^{22}$

Secondly, discounting practices in general are so pervasive in character and employed on such a regular basis by small and large businesses, that many assume it has a generally procompetitive nature. ${ }^{23}$ Posner remarked that 'if the practice is one employed widely in industries that resemble the monopolist's but are competitive, there should be a presumption that the monopolist is entitled to use it as well. ${ }^{24}$ This view is also adopted by many others who stress the fact that a great deal of bundling takes place in industries in which there appears to be considerable competition, and therefore they must have good efficiency explanations. ${ }^{25}$ In other words, bundling, including bundled discounts, may well have similar efficient characteristics when practiced by monopolists.

I argue against pre-judging monopolists' actions under any circumstances. The theoretical possibility of unilateral actions being carried out for efficiency reasons should, of course, form part of the examination process. However, to allow assumptions of a pro-competitive nature of bundled discounting practices to influence the subsequent analysis to more than a fair degree would be highly unfortunate.

Creating a set of coherent and effective liability standards for bundled discounting practices that are based on sound economic and legal principles should entail a careful balancing act. Over-expansion of monopolist power threatening the competitiveness of the market and in

${ }^{22}$ ibid.

${ }^{23}$ Sherman Act s.2 Joint Hearing: Academic Testimony Hr'g Tr. 136, Jan. 31, 2007

(Rubinfiled) stating that bundled discouting is 'quite ubiquitous and often is procompetitive'; Sherman Act s.2 Joint Hearing: Loyalty Discounts Session Hr'g Tr. 59, Nov.29, 2006 (Kattan) stating that 'the prevalence' of bundled discounts and discounts having a retroactive feature 'by firms that don't have market power and have no hope of excluding competitors would suggest... that there is a good possibility that the efficiency explanation for these practices is the dominant one.' ${ }^{24}$ Richard A. Posner, Antitrust Law ( $2^{\text {nd }}$ edn, UOC Press 2001) 253.

${ }^{25}$ Hazlett TW, 'Shedding Tiers for a-la-Carte? An Economic Analysis of Cable TV Pricing' (2006) 5 Journal on Telecommunications \& High Technology Law 253; David Evans and Michael Salinger, 'Why Do Firms Bundle and Tie? Evidence from Competitive Markets and Implications for Tying Law'(2005) 22 Yale Journal on Regulation 37. 
turn causing a reduction in consumer welfare is, of course, highly undesirable. However, there is also the real danger of chilling desirable business activities. A more rational test would, for example, analyse whether the unbundled prices are greater or lower than but-for levels and then consider the effects under both possibilities.

\section{Potential Efficiencies and Strategic Reasons for Bundled Discounting}

There are many efficiencies potentially associated with bundled discounts. These can be to lower a firm's costs; ${ }^{26}$ to reflect economies of scale or scope in either manufacturing or transacting; ${ }^{27}$ to induce existing customers to try new products or services and giving retailers incentives to promote particular product and service offerings, ${ }^{28}$ and maybe even to take advantage of the fact that different buyers have varying demand elasticities for individual goods and thus to price discriminate in a way that increase the firm's output and reduce distribution costs. ${ }^{29}$

However, what can be deduced from above is only that theoretically speaking, it is perceivable that a monopolist has perfectly innocent intentions in engaging in the bundling practices in question. This, however, should not automatically translate into zero liability.

Sound legal rules in such a market-oriented area of the law should be based on objective evaluations informed by rigorous economic analysis and guided by clear goals of the overall competition law regime. As consumer welfare is recognised widely as the central standard for competition law, ${ }^{30}$ I believe it should also be the fundamental criteria used to assess whether a certain cause of action should attract antitrust liability or not. Such an approach would entail, for example, that some of the efficiencies to be translated into an increase in consumer surplus, and not to be captured by intermediaries, such as dealers and agents.

\footnotetext{
${ }^{26}$ US Department of Justice, 'Section 2 Report' (n 1) p.96.

${ }^{27}$ David Evans and Michael Salinger, (n 25) pp. 37, 41.

${ }^{28}$ Sherman Act s. 2 Joint Hearing: Loyalty Discounts Session Hr'g Tr. 59, Nov.29, 2006 (Timothy J. Muris).

${ }^{29}$ Phillip E. Areeda and Herbert Hovenkamp, Antitrust Law (2007 Supp.) 263-64.

${ }^{30}$ Neelie Kroes 'European Competition Policy - Delivering Better Markets and Better Choices' <http://europa.eu/rapid/pressReleasesAction.do?reference=SPEECH/05/512> accessed on 2 July 2012; State Oil Co v Khan, 522 US 3, 15 (1997).
} 


\section{Is There a UNIFying TheORY OF HARM?}

The other major problem is that in the current economic thinking on bundling and tying there is no unifying theory of harm. There are a wide range of theoretical possibilities, including price discrimination, foreclosure or leverage of monopoly across markets, and softening of price competition. $^{31}$

The purpose of this section is to present an organised group of key theoretical possibilities in this area without detouring into the heavy and substantive economic analysis on the correctness of these theories and the extent to which they reflect why monopolists operate in reality. My goal is to qualify the theoretical complexity in this area. I will then demonstrate how this is a major hurdle in designing a rational legal test for bundled discounts in the next section of this paper.

\section{Price Discrimination}

In the case of mixed bundling, price discrimination can be achieved where two products (A and B) are offered separately at $£ 20$ and $£ 20$, but they are offered as bundle at $£ 30$. Those who value $A / B$ at more than $£ 20$ but the entire bundle at less than $£ 30$ will buy only $\mathrm{A} / \mathrm{B}$. Those who value the bundle at more than $£ 30$ will buy the bundle or one of the products by itself. This sort of scheme can bring customers into the market who value A and B separately at less than $£ 20$ but the bundle at more than $£ 30$. Walker notes that this form of price discrimination is likely to be procompetitive. However, the social welfare effect is actually ambiguous. ${ }^{32}$

\section{Entry Deterrence}

Incentives for new entrants into the market may be lowered because the monopolist has created/raised barriers for them to compete as efficient competitors. Buyers entering the rebate schemes can reduce the scale of rivals and thus increase their costs. In any case, customers will decide to break their contract with the monopolist only if it is compensated by

\footnotetext{
${ }^{31}$ Mike Walker, 'Bundling: Are US and European Views Converging?' (2008) 4 Euro. C. J. 275.

${ }^{32}$ ibid.
} 
lower price. ${ }^{33}$ Bundling may also make it economically unprofitable for an entrant to enter one market without simultaneously entering the second market, and this acts as an entry-deterring device. ${ }^{34}$

\section{Foreclosure to Leverage Monopoly across Markets}

By the same logic, competitiveness of a rival can be impaired through market foreclosure. With the rebate schemes in place, rivals can be forced to a smaller market share and thus will have higher unit costs in the presence of fixed costs, and will be marginalised or forced to exit the market. ${ }^{35}$

There are numerous versions of this entry deterrence argument. If product $\mathrm{B}$ is only useful when used in conjunction with product $\mathrm{A}$, then the monopolist of product A can simply foreclose the market for product B to other suppliers by bundling the two products together. Thus, the monopolist might be able to use its monopoly of product $A$ to also become a monopolist of product $\mathrm{B}$. Whether the dominant firm has an incentive to do this is not always clear. Nevertheless, the theory is that competitors tend to be foreclosed in the non-monopolised market so that in the long run they are eliminated. The monopolist can then set a higher price in the second market in the future to the extent that rivals driven out find it difficult to make a re-entry. In this way, consumer surplus could be further reduced in the medium and long run.

The other version of the entry deterrence argument is that bundling can be used by monopolists to price the competitive product lower, thus leading to market foreclosure. This is based on the idea that competition in bundles is fiercer than competition between individual products, since a firm that sells in bundles has to lose two margins instead of one when it fails to make a sale. ${ }^{36}$ This important factor induces the monopolist to compete even more aggressively. In this particular case, the short run benefit of lower prices could lead to consumer harm if outweighed by

\footnotetext{
${ }^{33}$ Nicholas Economides and Ioannis Lianos, 'The Elusive Antitrust Standard on Bundling in Europe and in the United States in the Aftermath of the Microsoft Cases' (2009-10) 76 Antitrust LJ 483.

${ }^{34}$ Aaron S. Edlin and Daniel L. Rubinfeld, 'Exclusion or Efficient Pricing? The "Big Deal" Bundling of Academic Journals'(2004) 72 Antitrust LJ 119.

${ }^{35}$ Economides (n 8) 124.

${ }^{36}$ Walker (n 31).
} 
longer term dynamic loss, such as through reduced innovation by new entrants. Consumer harm can also be caused by the rise in prices once potential entrants have disappeared. The worry is that the rival may conclude that fighting with the monopolist is unlikely to be profitable, resulting in them not innovating or entering in the first place. ${ }^{37}$

\section{Softening of Price Competition}

In theory, when the monopolist is engaged in bundling, any reduction in the price charged by a producer of only product B will lead to a smaller increase in demand for this supplier than would be the case if the monopolist was not bundling. This is because the number of consumers who would have switched in the absence of bundling to product $\mathrm{B}$ will now not switch in the presence of bundling because they value product $\mathrm{A}$ highly. If the benefit in cutting prices is lessened, a company will typically price higher. This is one way in which bundling can soften price competition and hence cause consumer harm. ${ }^{38}$

Another version of this theory is that bundling practices by a monopolist has the effect of increasing price differentiation. Depending on the strength of competition between suppliers of only product $\mathrm{B}$, this may lead to a softening of prices. ${ }^{39}$

\section{Externality Problems and the 'Prisoners' Dilemma'}

In any given situation, buyers would usually comply with the loyalty/requirement program rather than buying à-la-carte. The incentive is fuelled by externality problems: it seems rational to agree to it for a nominal individual discount, assuming that the wider market is not affected by its decision. ${ }^{40}$ However, once a large number of buyers buy under condition, the monopolist increases in market power and is able to increase both the a-la-carte and the bundled prices. ${ }^{41}$

Therefore, it cannot be inferred that complying with the bundled discounting arrangement necessarily makes buyers better off than in the

\footnotetext{
${ }^{37}$ ibid.

${ }^{38}$ ibid.

${ }^{39}$ ibid.

${ }^{40}$ Joseph Farrell, 'Deconstructing Chicago on Exclusive Dealing' (2005) 50 Antitrust Bulletin 465, 476.

${ }^{41}$ Economides (n 8) 130-1.
} 
but-for world. ${ }^{42}$ This is why bundling can make consumers worse off even where they have the choice of whether or not to comply with the offerings. Their individually rational decisions collectively strengthen the monopolist, allowing it to increase both the à-la-carte and bundled prices, thereby extracting more surplus than in unbundled monopoly.

This, as theorised by Economides, is something similar to the 'prisoners' dilemma', where both buyers accept the bundling deal with the aim of putting themselves in a better situation but both become worse off than if neither accepted the deal. ${ }^{43}$ Additionally, the externality problems are made worse when the relevant buyers are not consumers, but dealers and agents alike who are the intermediaries that resell to others. It has been argued that intermediate buyers are even more likely to agree to such rebate schemes because they can pass on much if not all of the price increase to downstream buyers and thus externalise an even higher percentage of the harm. ${ }^{44}$

\section{Switching Costs}

As highlighted by the EU Guidance, 'retroactive rebates may foreclose the market significantly, as they may make it less attractive for customers to switch small amounts of demand to an alternative suppler, if this would lead to loss of the retroactive rebates. ${ }^{45}$

Furthermore, buyers who once purchased a large percentage of their needs from one seller may not want to buy a small percentage of their needs from another, for reasons such as the extra costs and effort in training personnel in a new product and compatibility issues. Therefore, it

\footnotetext{
${ }^{42}$ Einer Elhauge and Abraham L. Wickelgren, 'Anti-Competitive Exclusion and Market Division through Loyalty Discounts' Harvard M. Olin Centre for Law, Economics, and Business, Discussion Paper 707

$<$ http://www.law.harvard.edu/faculty/elhauge/pdf/Elhauge-Wickelgren\%20AntiCompetitive\%20Exclusion.pdf $>$ accessed on 2 July 2012.

${ }^{43}$ Economides (n 8) 132.

${ }^{44}$ Jose Miguel Abito and Julian Wright, 'Exclusive Dealing with Imperfect Downstream Competition' (2008) 26 International Journal of Industrial Organization 227.

${ }^{45}$ EU Commission, Guidance (n 13) para 40.
} 
is possible that the impact of the loyalty/requirement program is larger than the share thresholds on which it is based. ${ }^{46}$

\section{E. A general Survey of the Current Legal LaNdSCAPE}

In parts $\mathrm{C}$ and $\mathrm{D}$, I have illustrated how the theoretical literature on bundling and bundled discounts in particular has generated a variety of possibilities. Kobayashi gives an excellent summary of the main problems arising from the conceptual chaos: literature in this area is 'sparse'. ${ }^{47}$ Moreover, 'the incremental cost tests and the consumer welfare tests may be difficult to administer', and 'tests based on whether an equally efficient competitor could be excluded may condemn welfare-increasing behaviour. $^{48}$

I am now going to illustrate how such difficulties have revealed themselves in practice.

\section{US Case Law}

SmithKline Corp. $v$ Eli Lilly \& Co. ${ }^{49}$ was one of the earliest cases in the US involving bundled discounts. The court found that SmithKline would have had to offer a rebate of more than $20 \%$ on its one product to match Lilly's bundled rebate, and if SmithKline had done so, its drug would not have been sufficiently profitable to justify remaining in the market, even if SmithKline had been able to 'reduce its costs of goods to Lilly's level. ${ }^{50}$ The court concluded that because Lilly's bundled rebates would have excluded SmithKline even if the latter firm were an equally efficient producer, there was a violation of s. 2 of the Sherman Act by Lilly in using its monopoly power in two products to exclude the slightly less efficient' SmithKline from the market for a competitive product. ${ }^{51}$

\footnotetext{
${ }^{46}$ Economides (n 8) 133-4.

${ }^{47}$ Bruce Kobayashi, 'The Economics of Loyalty Discounts and Antitrust Law in the United States' (2005) 1 Competition Policy International 115.

48 ibid 147.

49427 F. Supp. 1089 (E.D. Pa. 1976), aff'd, 575 F.2d 1056 (3d Cir. 1978).

${ }^{50}$ ibid 110809; US Department of Justice, 'Section 2 Report' (n 1).

51 ibid 1128-29; US Department of Justice, 'Section 2 Report' (n 1).
} 
However in Ortho Diagnostic Systems which involved similar bundled-pricing plan, the court found no violation of s.2. ${ }^{52}$ The Court framed the key question as 'whether a firm that enjoys a monopoly on one or more of a group of complementary products, but which faces competition on others, can price all of its products above average variable cost and yet still drive an equally efficient competitor out of the market. ${ }^{53}$ The court further explained that a plaintiff 'must allege and prove either that (1) the monopolist has priced below its average variable cost or (2) the plaintiff is at least as efficient a producer of the competitive product as the defendant, but that the defendant's pricing makes it unprofitable for the plaintiff to continue to produce the product. ${ }^{54}$ And because Ortho did not claim that it could not sell its products at a profit as a result of Abbott's bundled discounting, the count found no s.2 violation.

The focus on the actual plaintiff's costs and whether the actual plaintiff was an equally efficient competitor have since been criticised $^{55}$ and amended in Cascade Health Solutions ${ }^{56}$ to be the costs of a hypothetical equally efficient competitor. The test became whether a hypothetically equally efficient producer of the competitive product could meet the defendant's discount. ${ }^{57}$

Virgin v British Airways ${ }^{58}$ also involved a bundled-discount claim, despite the fact that it was primarily viewed as a single product loyalty discount case. Virgin Atlantic alleged British Airways' rebates would result in corporate customers that purchased tickets on British Airways monopoly routes having an incentive to purchase British Airways tickets on routes where Virgin Atlantic competed, even though the latter charged less. ${ }^{59}$ The court however refused to impose liability for the main reason

52 Ortho Diagnostic Systems, Inc. v Abbott Laboratories, Inc. 920 F. Supp. 455

(S.D.N.Y. 1996).

53 ibid. 467.

54 ibid. 469.

${ }^{55}$ E.g. Areeda and Hovenkamp (n 29).

${ }^{56}$ Cascade Health Solutions v PeaceHealth, 515 F.3d 883, 905-08 ( $9^{\text {th }}$ Cir. 2008).

57 ibid.

${ }^{58}$ Virgin Atlantic Airways Ltd v British Airways plc 257 F3d 256 (2d Cir 2001).

${ }^{59}$ ibid 580. 
that Virgin Atlantic provided no factual evidence to support the theoretical possibility of below-cost pricing. ${ }^{60}$

These cases provide a good illustration of the line of thought deployed by some circuits of the US Court of Appeal: accepting mixed bundling as lawful if the effective price charged for one or more products in the bundle is not below some measure of cost.

However, there are other circuits in the US that have adopted a more aggressive attitude, considering that bundled discounts may amount to anticompetitive behaviour even when the dominant firm would not be liable under a cost-based rule such as that adopted in cases like Cascade Health Solutions. ${ }^{61}$

This approach is more enforcement oriented: the central issue is whether bundled pricing strategies may foreclose or exclude equally efficient rivals, even if the discount results in prices that are above the dominant firm's costs. ${ }^{62}$ In such cases the courts make a more direct analogy between bundled discounts and tying in a traditional sense, as all these practices may lead to anticompetitive market foreclosure.

The Court of Appeals for the Third Circuit made an explicit analogy between bundled rebates and tying in LePage's. ${ }^{63}$ The defendant, 3M, argued its bundled rebates were legal as it never priced its transparent tape below its cost. Instead of examining whether 3M's price was below a certain measure of its cost, the court in this case applied an anticompetitive foreclosure test, or an abbreviated rule of reason approach: 'the principal anticompetitive effect of bundled rebates... is that when offered by a monopolist they may foreclose portions of the market to a potential competitor who does not manufacture an equally diverse group of products and who therefore cannot make a comparable offer. ${ }^{64}$ The court held that 3M's practice had 'long-term' anticompetitive effects,

\footnotetext{
${ }^{60}$ ibid 580-1.

${ }^{61}$ E.g. SmithKline Corp. v Eli Lilly \& Co., 575 F.2d 1056 (3d Cir. 1978); LePage's Inc. v 3M, 324 F.3d 141 (3d Cir. 2003); United States v Dentsply Int'l, Inc., 399 F.3d 181 (3d Cir.2005).

${ }^{62}$ Economides and Lianos, (n 33).

${ }^{63}$ LePage's Inc. v 3M, 324 F.3d 141, 155 (3d Cir.2003).

${ }^{64}$ ibid para 57.
} 
without $3 \mathrm{M}$ offering any adequate business justifications for its practices. $^{65}$

In affirming the finding of illegal conduct under s. 2, the Third Circuit Court of Appeals in LePage' $s$ ' held that the rebates program 'has made it very difficult or impossible for competitors to engage in fair competition. ${ }^{67}$ This case has since been correctly criticised as being too vague and not providing any useful guidance. ${ }^{68}$

However, the bigger source of controversy is the fact that the anticompetitive foreclosure test applied by the court in this case meant that it is possible to cause s. 2 violation even though the excluded rival was less efficient than the defendant. As the dissenting judge in this case remarked, 'LePage's is not as efficient a tape producer as 3M', which makes this case an uncomfortable departure from the previous line of authorities on this matter, which all adopted some sort of a price-cost test. $^{69}$

Subsequently the district court in Cascade Health Solutions based their bundling instruction on LePage's standard. ${ }^{70}$ However, the district court's decision was reversed when the case reached the Ninth Circuit for the reason that it potentially allowed for liability even when the plaintiff was less efficient than the defendant, and 'it does not consider whether the bundled discounts constitute competition on the merits, but simply concludes that all bundled discounts offered by a monopolist are anticompetitive with respect to its competitors who do not manufacture an equally diverse product line. ${ }^{71}$ It was thus held that an antitrust plaintiff can prove that a bundled discount was exclusionary or predatory under $\mathrm{s}$. 2 of the Sherman Act only if the plaintiff establishes that, 'after allocating the discount given by the defendant on the entire bundle of the products to

\footnotetext{
65 ibid para 99.

${ }^{66}$ LePage's Inc. v $3 M$ cert. denied, $124 \mathrm{~S} \mathrm{Ct} 2932$ (2004).

${ }^{67}$ ibid para 145 (quoting the trial court).

${ }^{68}$ E.g., Masimo Corp. v Tyco Health Care Group, L.P. No. CV 02-4770 MRP, 2006

WL 1236666, *14 (C.D. Cal. Mar. 22, 2006); Information Resources, Inc. v Dun \&

Bradstreet Corp., 359 F. Supp.2d 307 (S.D.N.Y.2004); Invacare Corp. v Respironics Inc., No. 1:04 CV 1580, 2006 WL 3022968, *12 (N.D. Ohio Oct. 23, 2006).

${ }^{69}$ LePage's (n 63) para 191 (Greenberg. J, dissenting).

${ }^{70}$ Cascade Health Solutions (n 56) at 11211-2.

${ }^{71}$ ibid at 11214.
} 
the competitive product or products, the defendant sold the competitive product or products below its average variable costs of producing them. ${ }^{, 72}$

\section{Recent US Political Developments}

In reaching its decision, the court in Cascade Health Solutions in part followed the proposal of a discount attribution/allocation test by the Antitrust Modernisation Commission (AMC). ${ }^{73}$

According to the AMC test, the entirety of the discounts on a bundle is attributed to the more competitive of the two products. It then tests whether the resulting hypothetical 'effective' price established through this method of attribution is above a measure of avoidable cost. ${ }^{74}$ The AMC uses the words 'incremental costs' in its cost criterion, often average variable cost is used instead. ${ }^{75}$ An antitrust violation would be found in cases where (1) the effective price is below the average variable cost of product $\mathrm{B}$ of the monopolist in product $\mathrm{A}$; and (2) the dominant firm is likely to recoup its losses; and (3) the requirement contract is likely to have anti-competitive consequences. ${ }^{76}$

The AMC also proposed that a cost-based safe harbour should be established if the hypothetical effective price established through this three-stage attribution process is above the avoidable cost of the monopolist for product B. ${ }^{77}$

The AMC's proposition was later embraced by the US Department of Justice in its Section 2 Report $^{78}$ In cases where bundle-to-bundle competition was not possible, the DOJ proposed a 'discount allocation safe harbour', whereby there would only be abuse of s. 2 if the plaintiff showed that the defendant sold the competitive product at an imputed price (i.e. the price after allocating all discounts and rebates attributable to

\footnotetext{
72 ibid at 11233-4.

${ }^{73}$ Antitrust Modernization Commission, 'Report and Recommendations', 88 (2007) $<$ http://govinfo.library.unt.edu/amc/report_recommendation/amc_final_report.pdf $>$ accessed on 2 July 2012.

74 ibid 12, recommendation 17.

${ }^{75}$ Economides (n 8) 137, esp. fn 55.

${ }^{76}$ ibid.

${ }^{77}$ Antitrust Modernization Commission (n.72).

${ }^{78}$ Department of Justice, 'Section 2 Report' (n 1).
} 
the entire bundle to the competitive product) that was below the product's incremental costs. ${ }^{79}$

This report, however, has since been withdrawn by the DOJ Antitrust Division under the Obama administration. ${ }^{80}$ The position of the new administration with regard to the price-cost based test is still unclear. ${ }^{81}$

The withdrawal itself is quite significant in that it marked an important change in the attitude of the US authorities regarding the treatment of single-firm conduct in general. Recall that just a few years ago there were commentators remarking that the authorities and courts in the US have generally adopted a less interventionist approach towards rebates and discounts, preferring to focus on whether anti-competitive effects are realistic or not. ${ }^{82}$ By 2009 the US authorities were seriously questioning the notion that most unilateral conduct is driven by efficiency and that monopoly markets are generally self-correcting. The withdrawal of the 'Section 2 Report' shows a new reluctance on relying on the marketplace alone to ensure that competition and consumers are protected, and that overly cautious approaches and hesitancy in the face of potential abuses by monopoly firms are no longer supported or encouraged. Indeed, the press release states that "withdrawing the section 2 report is a shift in philosophy and the clearest way to let everyone know that the Antitrust Division will be aggressively pursuing cases where monopolists try to use their dominance in the marketplace to stifle competition and harm consumers. ${ }^{83}$

\section{EU Case Law and the Foreclosure Standard}

EU case law draws no distinction between single product rebates and bundled discounts. Instead, the case law distinguishes between volume

\footnotetext{
79 ibid.

${ }^{80}$ Department of Justice, Press Release, 'Justice Department Withdraws Report on Antitrust Monopoly Law’ (May 11 2009)

$<$ http://www.justice.gov/atr/public/press_releases/2009/245710.htm $>$ accessed on 2 July 2012.

${ }^{81}$ Economides and Lianos (n 33) 18.

${ }^{82}$ Christian Ahlborn and David Bailey, 'Discounts, Rebates and Selective Pricing by Dominant Firms: A Trans-Atlantic Comparison' (2006) 2 Eur. Competition J 101.

${ }^{83}$ Department of Justice, Press Release (n 80).
} 
(quantity discounts), which are legal per se, and loyalty rebates, which are illegal in most circumstances. The European Courts have so far adopted a foreclosure test without requiring any evidence to show that the discount on the competitive product was below an appropriate level of the defendant's cost.

Cases such as Hoffmann-La Roche ${ }^{84}$ and BPB Indus. Plc ${ }^{85}$ have shown that a dominant firm can grant quantity discounts without infringing art. 102 (formerly, art. 82) of the Treaty on the Functioning of the European Union ${ }^{86}$ if these are offered on equal terms to all customers of the firm, and the discounts reflect efficiency gains: e.g. cost savings, economies of scale. On the other hand, loyalty rebates rewarding exclusivity or strongly encouraging the customer to stay with the supplier may be considered illegal under the same article.

In the Hoffmann-La Roche case, for example, the discounts were conditioned upon the customer obtaining from the dominant defendant firm all or most of its requirements on vitamins. The court said that the rebate was conditional on purchasing mainly or exclusively from the dominant undertaking and therefore abusive in principle. It subsequently ruled that the conditional rebates in question foreclosed the access of rival products in the market, and therefore amounted to unlawful tie-in and infringed art. $82(\mathrm{~d}) .{ }^{87}$

Recent European case law has focused on targeted retroactive discounts producing an exclusionary and loyalty effect. Such practices are generally found to violate art. 102 when they can cause, without any objective economic justification, the entry of rivals into the market to be more difficult, thus creating an exclusionary effect. ${ }^{88}$

\footnotetext{
${ }^{84}$ Case 85/76 Hoffmann-La Roche \& Co. v Commission, 1979 ECR 461 (ECJ)

${ }^{85}$ Case T-65/89 BPB Indus. Plc v Commission, 1993 ECR II-389 (Court of First Instance).

${ }^{86}$ Consolidated Version of the Treaty on the Functioning of the European Union [2010] C83/47< http://eurlex.europa.eu/LexUriServ/LexUriServ.do?uri=OJ:C:2010:083:0047:0200:EN:PDF> accessed on 2 July 2012.

${ }^{87}$ Hoffmann-La Roche (n 84) 89-90, 110-11.

${ }^{88}$ E.g., Case C-95/04 British Airways v Commission, 2007 ECR I-2331, 68-69.
} 
In Michelin II, ${ }^{89}$ the Court of First Instance (CFI) found standardised sales targets over a relatively long period were abusive under art. 82. The specific nature of the loyalty scheme was such that it put pressure to buy wholly or mainly from Michelin and effectively to tie the dealer to Michelin. ${ }^{90}$

A remarkable fact of the Michelin II decision was that the CFI found it irrelevant that the market shares and the sales of Michelin fell during the rebate scheme, reasoning that the fall in Michelin's sales and market shares would have been even greater had the rebate scheme not been adopted. ${ }^{91}$ The central consideration of the court was that 'not all competition on price can be regarded as legitimate', ${ }^{92}$ highlighting a strong contrast between EU and US in judicial attitude towards this type of 'price' competition. ${ }^{93}$

British Airways tested the CFI's assessment of the exclusionary character of its reward scheme before the European Court of Justice. ${ }^{94}$ Upholding the commission's prohibition decision, Advocate General Kokott expressed that: ${ }^{95}$

Article 82, like the other competition rules of the Treaty, is not designed only or primarily to protect the immediate interests of individual competitors or consumers, but to protect the structure of the market and thus competition as such (as an institution).... In this way, consumers are also indirectly protected. Because where competition is damaged, disadvantages for consumers are also to be feared.

Slightly reformulating the restrictive position of Michelin II and being more explicit in its language, the judges of the ECJ adopted an approach

\footnotetext{
${ }^{89}$ Case T-203/01 Manufacture Française des Pneumatiques Michelin v Commission (Michelin II) 2003 ECR II-4071.

${ }^{90}$ ibid 245.

91 ibid.

92 ibid 97.

${ }^{93}$ Economides and Lianos (n 33) 21.

${ }^{94}$ British Airways (n 88).

95 ibid, Opinion of AG Kokott < http://eur-

lex.europa.eu/LexUriServ/LexUriServ.do?uri=CELEX:62004CC0095:EN:NOT> accessed on 2 July 2012.
} 
where the exclusionary effects can be 'counterbalanced' by 'advantages in terms of efficiency which also benefit the consumer. ${ }^{96}$

\section{The EU Commission and the Rise of the Price-Cost Test}

What we saw from the above overview of the case law by the EU judiciary was that loyalty inducing schemes were prohibited per se, and they are symptomatic of a broader trend in the application of EC law to unilateral conduct, which has not been based on sufficient economic analysis.

With the aim of reconsidering the law and policy under the then article 82 (currently, art. 102), the Commission published the Discussion Paper which suggested a predatory pricing approach for exclusionary practices. ${ }^{97}$ The incremental prices are compared to long run incremental costs. If it appears that incremental prices are below long run incremental costs, then we need to see whether there is any potential for exclusionary effect covering a significant portion of the market. The bundling in question may be abusive if it does. ${ }^{98}$ This approach was finally adopted in the Commission Guidance. ${ }^{99}$

Additionally, the Commission rejected the distinctions among quantity loyalty, and target rebates that were previously employed by the courts. Instead, it divided rebate practice into two categories. The first was the single-product rebate systems of dominant firms that have effects in the dominated market. The Commission treated this first type as a form of price-abuse and advocated examining them under price-cost standards. This was an important shift from the current approach adopted by the CFI and the ECJ on rebates, which employs the anticompetitive foreclosure standard and does not provide for a safe harbour for discount practices. Secondly, the Discussion Paper separately categorised mixed bundling practices or bundled discounts that produce effects on other markets or on different products of the same market. There is some confusion caused

\footnotetext{
${ }^{96}$ British Airways (n 88) para 86.

${ }^{97}$ European Commission, 'DG Competition Discussion Paper on the Application of Article 82 of the Treaty to exclusionary abuses', December 2005 (hereinafter, Discussion Paper) <http://ec.europa.eu/competition/antitrust/art82/discpaper2005.pdf> accessed on 2 July 2012.

98 ibid.

${ }^{99}$ EU Commission, Guidance (n 13).
} 
by the fact that the Commission, while analysing bundled discounts in the section devoted to tying practices, also classified them as a pricing abuse. ${ }^{100}$ I will elaborate on the price/non-price dichotomy in the Commission's approach in later parts of this paper.

The EU approach to bundling under art. 102 is not clear mainly due to the fact that the EU Commission is constrained by the European's Courts' case law, which is not always consistent with the Commission's preferred approach.

\section{F. Substantive Categories: Defects in CuRRent Tests}

To put it in the simplest way, what the general survey of the current legal landscape as above has demonstrated is the unsatisfactory nature of the antitrust standards on bundled discounting practices in the US and the EU. The problem is not merely to do with the great theoretical difficulties in finding a single formulation that captures the essence of this complex area of competition law; it also has everything to do with how the judiciary and the relevant authorities have so far been unable to translate however little economic rationales there are into effective legal rules. I will now analyse some of the major defects in the current rules and tests in the US and the EU. This will include the test proposed by the AMC which, despite having been withdrawn, still provides much valuable food for thought.

\section{Is there a Need for 'Safe Harbours'?}

Geradin makes the point that even if we already have an antitrust regime that is coherently and conceptually clear, it is likely to require complex assessments both for the relevant authorities ex-post and the firms ex-ante, which will involve the deployment of significant resources. ${ }^{101}$ Such an assessment will always involve a degree of uncertainty. Safe harbours add certainty to administrative rules on bundled discounts.

Baumol asserts that 'in a world in which vigorous competition is all too easily mistaken for predation, and in which firms can unintentionally overstep the line, it is important to provide managers with guidelines as unambiguous as the issue permits, to enable them to tailor their decisions

\footnotetext{
${ }^{100}$ EU Commission, Discussion Paper (n 97).

${ }^{101}$ Geradin (n 5) 41-70.
} 
in a way that ensures compliance with the law and minimises vulnerability to anticompetitive lawsuits intended to handicap vigorous competition. ${ }^{102}$

Thus, the value of 'safe harbours' is giving firms 'immediate assurance ${ }^{103}$, without having to invest significant amounts of time and resources in a full-scale analysis on the prospects of attracting challenges by the competition authorities, or indeed liabilities. This could only work if (1) the 'safe harbours' are clearly marked out; and (2) the competition authorities can commit themselves to it by not raising challenges on those schemes falling inside the safe harbour.

The European Commission stated in its Guidance that, 'as long as the effective price remains consistently above the LRAIC of the dominant undertaking, this would normally allow an equally efficient competitor to compete profitably notwithstanding the rebate. ${ }^{104}$ However it has also showed its willingness to deviate from such a standard in certain cases to protect less efficient competitors by recognising that in certain circumstances a less efficient competitor may also exert a constraint which should be taken into account when considering whether a particular price-based conduct leads to anticompetitive foreclosure.' 105 This uncertainty is regrettable in that firms may accordingly avoid pursuing certain pro-competitive rebate schemes because they are concerned by the possibility of ensuring antitrust implications.

On the other hand, where bundle-to-bundle competition is not possible, the 'discount allocation safe harbour' devised in the US DOJ Section 2 Report was later withdrawn under the Obama administration. ${ }^{106}$ The fact that the new administration's stance is unclear only adds to the uncertainties in this area.

What we need, therefore, is a clear and unambiguous position on the issue of 'safe harbours' in both the US and Europe that will both save resources for the competition authorities in their investigation of the

\footnotetext{
${ }^{102}$ William J. Baumol, 'Predation and the Logic of the Average Variable Cost Test' (1996) 39. Journal of Law and Economics 49, 51.

${ }^{103}$ Geradin, (n 5).

104 EU Commission, Guidance (n 13) para 43 (emphasis added).

105 ibid para 24.

${ }^{106}$ Department of Justice, Press Release (n 80).
} 
conduct in question, as well as provide useful guidance to the firms in their efforts to devise better strategies that are competitively safe. ${ }^{107}$

\section{What Quantity of the Competitive Product should be Used?}

The AMC used the total sales quantity of the 'competitive product' in calculating the hypothetical attribution price, whereas the EU made a distinction between the 'contestable' and 'incontestable' parts of the demand. ${ }^{108}$

The EU Guidance Paper has defined the 'contestable part of the market' as 'the amount for which the customer may prefer and be able to find substitutes. ${ }^{109}$ In applying this standard in the Intel decision, the European Commission notes that the contestable part of the market can be small. ${ }^{110}$ The fact that in many markets, a significant portion of the sales of the dominant firm is uncontested by competitors is due to a number of considerations. These can include factors such as reputation, fear of punishment from the executives following a decision not to buy from the dominant firm, limited competitor production capacity and complementary investments by buyers of the dominant product. ${ }^{111}$

Economides has argued that the EU's approach is the correct one for the reason that a monopolist is already able to sell units at full price in relation to the incontestable part of the buyers' demand. Therefore, the requirement/loyalty 'discount' is in fact aimed to win for the dominant firm the contestable part of the demand. Thus it is this part of the demand that constitutes the appropriate number of units to which the attribution is applied. ${ }^{112}$ This element is crucial to the discount attribution test because typically 'the liability test will be more likely to find liability if the

\footnotetext{
107 Jonathan M. Jacobson, 'Exploring the Antitrust Modernization's Proposed Test for Bundled Pricing' (Summer 2007) Antitrust 22.

${ }^{108}$ EU Commission, Guidance (n 13) para 39.

109 ibid; see also Michelin II (n 89) paras 162-3; British Airways (n 88) paras 277-8.

${ }^{110}$ COMP/C-3/37.990 (13 May 2009)

$<$ http://ec.europa.eu/competition/antitrust/cases/dec_docs/37990/37990_3581_11.pdf> accessed on 2 July 2012.

${ }^{111}$ Economides (n 8) 30.

112 ibid 31.
} 
discount is applied to the contestable units rather than the all sales of the monopolist. ${ }^{, 113}$

\section{Which Company's Costs should be Used?}

The dominant firm's costs are used to calculate avoidable cost in both the AMC and the EU tests. Due to the presence of economies of scale, a monopolist with high market share would incur lower average costs than rivals who are equally efficient (i.e. the same average cost function), only producing at lower market share.

The question is whether such a rival should be deemed less efficient even if it would have the same level of average cost as the dominant firm if it had the same scale of production. ${ }^{114}$ In fact, it has been pointed out by Elhauge that the monopolist is more likely to be found to have no liability because the test has already been weakened by the large scale of the monopolist: an effect of its anticompetitive actions in the first place. ${ }^{115}$ This is equally relevant in cases where the products of the dominant firm and the rival differ, because the costs can be adjusted to take into account the quality differences.

\section{The Desirability of an Efficiency Filter}

The idea of the discount attribution test was to eliminate claims from inefficient competitors. However, even higher cost rivals can constrain market price in the presence of monopoly pricing. ${ }^{116}$ The attribution test can be criticised on the ground that it automatically excluded inefficient rivals, which could lead to a reduction in consumer surplus and an increase in allocative inefficiency. ${ }^{117}$ Indeed, addressing this concern, some have even advocated the imposition of a strict pass-on requirement for any efficiency gains that the defendant advances as a justification for the adoption of the practice in question. This is based on the notion that

\footnotetext{
113 ibid.

${ }^{114}$ Economides and Lianos (n 33 ) 20-24.

115 Einer Elhauge (n 15).

116 Jonathan B. Baker, 'Predatory Pricing After Brooke Group: An Economic

Perspective' (1994) 62 Antritrust Law Journal 585, 591.

${ }^{117}$ Einer Elhauge, 'Defining Better Monopolization Standards' (2003) 56 Stan. L. Rev. $253,320-23$.
} 
the primary goal of antitrust law may be the protection of the final consumer from wealth transfers. ${ }^{118}$

Despite recognising that in certain circumstances a less efficient competitor may also exert a constraint which should be taken into account when considering whether a particular price-based conduct leads to anticompetitive foreclosure,' 119 the European Commission uses the price/cost test as an efficiency filter to identify those competitors who are at least as equally efficient as the dominant firm before moving to examine whether there exists a case of anticompetitive foreclosure. ${ }^{120}$ In other words, if it is a price-based exclusionary conduct, then the Guidance will treat the less-efficient competitors as less worthy of protection from the competition law regime. The Commission has not provided good economic justifications for this.

As mentioned above, the introduction of price/non-price based dichotomy also raises concern. Unlike price-related abuses, the exclusion of less-efficient competitors remains an important consideration for nonprice based exclusionary conduct, such as tying. ${ }^{121}$ Once the other two conditions are fulfilled, i.e. (1) the undertaking's dominant position in the tying market, and (2) the fact that the tying and the tied products are distinct, the Guidance does not exclude further analysis of the practice to detect anticompetitive foreclosure. ${ }^{122}$ Again, such a distinction does not seem to have drawn upon advances in economics, thereby creating many conceptual difficulties.

The other issue is that the 'efficient competitor' filter does not immunise rebates from antitrust challenges which are based on the anticompetitive foreclosure test developed by the European judiciary. For example, in Intel, the Commission observed that the efficient competitor analysis is only 'one possible way of showing whether Intel's rebates and payments were capable of causing or likely to cause anticompetitive foreclosure. ${ }^{123}$ The frequent reference to the case law of the ECJ and of

\footnotetext{
118 Robert H. Lande, 'Wealth Transfers as the Original and Primary Concern of Antitrust: The Efficiency Interpretation Challenged' (1982) 34 Hastings L. J. 65.

${ }^{119}$ EU Commission, Guidance (n 13) para 24.

${ }^{120}$ Economides and Lianos (n 33 ) 30.

${ }^{121}$ EU Commission, Guidance (n 13) para 27.

122 ibid paras 52-58.

${ }^{123}$ Intel (n 110) para 925.
} 
the CFI in the Commission's decisions creates uncertainty about the application of the price-cost test in future cases. ${ }^{124}$

\section{Recoupment is Unnecessary: the Predation Myth}

Dominant firms can set the bundled prices at whatever level they like. Therefore, in theory, the à-la-carte prices can be increased simultaneously to levels above the 'but-for' levels. To a buyer, however, there would be a 'discount', if only illusory. ${ }^{125}$ Profit sacrifice, therefore, is not a necessity. ${ }^{126}$ The EU Commission has supported the idea that no profit sacrifice is required on the dominant firm's part in a loyalty/requirement rebate: 'Conditional rebates can have such [actual and potential foreclosure] effects without necessarily entailing a sacrifice for the dominant undertaking.' 127 'In this regard, the assessment of the conditional rebates differs from that of predation, which always entails a sacrifice. $^{, 128}$

However, some commentators have rightly questioned whether the frequency of such illusory discounts is sufficient to shape legal rules. ${ }^{129}$ Kattan, in particular, was keen to draw our attention to the great difficulty in assessing the real reasons behind any price change for out-of-bundle products. It is possible that such changes are related to quality, performance, and product attributes, or indeed for a variety of other supply and demand reasons without it being a 'penalty' that the monopolist has imposed. ${ }^{130}$ Indeed, this is one of the reasons that US DOJ in its Section 2 Report has suggested screens and safe harbours to be put in place to add certainty without harming antitrust enforcement. ${ }^{131}$

\footnotetext{
${ }^{124}$ Economides and Lianos (n 33) 34.

125 Patrick Greenlee, David S. Reitman, and David S. Sibley, 'An Antitrust Analysis of Bundled Discounts' (2008) 26(5) Int L J Indus. Org 1132.

${ }^{126}$ Daniel L. Rubinfeld, '3M's Bundled Rebates: An Economic Perspective' (2005) 72

U. Chi L. Rev. 243.

${ }^{127}$ EU Commission, Guidance (n 13) para 37.

128 ibid.

${ }^{129}$ Sherman Act s.2 Joint Hearing: Loyalty Discounts Session Hr'g Tr. 59, Nov.29, 2006 (Kattan).

${ }^{130}$ ibid.

131 Department of Justice, 'Section 2 Report' (n 1).
} 
The key issue, again, is the theoretical complexity and the difficulty in building a reliable tool to assess the potential harm that can be caused by such bundled discounting arrangements. This raises the question of whether the correct legal standard should focus on the conduct's effect on competition rather than its relationship to defendant's cost structure.

\section{The AMC Attribution Test Fails in Cases of Production Differentiation}

In cases where the rival's products offering differs either in variety or in quality, it makes little sense to use the dominant firm's costs to evaluate the survival of the rival's production. When the products are differentiated, there may be an increase in consumer surplus from the presence of added varieties and qualities offered by the competitors even if they price above that of the dominant firm. ${ }^{132}$ For these reasons, the AMC test fails as an appropriate measuring tool in the presence of product differentiation.

Additionally, it may be difficult for a rival to calculate the effective price offered by the monopolist to particular buyers accurately, for the reason that the price paid by a particular buyer for the monopolist's product $B$ is usually dependent upon the sales of product $A$ by the same monopolist to the same buyer. This makes the price of product B opaque to any rival, who will in turn find it hard to match that price on product $\mathrm{B}$. This uncertainty is probably going to soften price competition, something that has skipped the AMC's attention in their design of the attribution test. ${ }^{133}$

\section{Tying vs. Bundled Discounts in the Commission's Test}

There is confusion in the EU Commission's approach as to whether bundled discounts should be assessed as a type of tying abuse or as a pricing abuse. ${ }^{134}$ The Commission acknowledged in its Discussion Paper that the distinction between mixed bundling and pure bundling (tying) is

\footnotetext{
132 Nicholas Economides, 'Quality Variations in the Circular Model of VarietyDifferentiated Products' (1993) 23 Regional, Sci \& Urb Econ 235.

133 Economides (n 8).

${ }^{134}$ EU Commission, Discussion Paper (n 97) paras 142-176.
} 
not 'necessarily clear-cut'. ${ }^{135}$ It explained that this was so because mixed bundling may come close to pure bundling when the prices charged for the individual offerings are high, and in such a case, mixed bundling can have very similar effect on competition as tying. ${ }^{136}$

However, in other parts the Commission remarks that in mixed bundling, none of the products is 'tied' in the traditional sense. ${ }^{137}$ Nevertheless, the Discussion Paper seems to recognise that coercion in tying and inducement in mixed bundling may produce the same effects on customer choice. ${ }^{138}$

Adding to the confusion, the Discussion Paper makes a distinction between what the Commission calls 'commercial tying' (mixed bundling) and 'contractual tying' and decides that only when the discount is so large that 'efficient competitors offering only some but not all of the components, cannot compete against the discounted bundled that a bundled discount was found to infringe Article 82. ${ }^{139}$

However, in the subsequent Guidance the Commission took a slightly different approach to the same problem. Despite adopting a similar spirit by including 'multi-product rebates' within the tying/bundling category, the Guidance chooses to make a distinction between price-based and non-price-based exclusionary conduct, instead of that between commercial and contractual tying. ${ }^{140}$

The European court thus acknowledged that bundled discounts may, in certain circumstances, have an equivalent effect to tying. ${ }^{141}$ The Guidance however has not made clear the conceptual difference between bundling and tying. Confusion could arise in cases where the same practices could be evaluated under either the price-cost test for mixed bundling, or the anticompetitive foreclosure test for tying. This is obviously a highly unsatisfactory situation.

\footnotetext{
135 ibid para 112 .

136 ibid.

137 ibid para 181 .

138 ibid para 182.

139 ibid para 189.

${ }^{140}$ EU Commission, Guidance (n 13), esp. paras 59-61.

${ }^{141}$ Case T-201/04, Microsoft Corp. v Commission, 2007 E.C.R. II-3601, para 908 (Crt. First Instance). Although the Court did not indicate if it will adopt the same standard as that for tying, the language used indicates that the CFI embraces the tying analogy.
} 


\section{G. Purposes of Antitrust Law and the Fundamental Limitations of ECONOMIC ANALysis: THE BROAdER PICTURE}

\section{How Cautious Should We Be?}

It should be clear by now that the area of bundled discount really is one of the most elusive areas of modern competition law. The complexity of the economics behind it contributes greatly to the confusion for three main reasons: (1) there are different theories of potential harm from bundling; (2) there are different short run effects: bundling can soften prices in the short run or raise them; and (3) whether bundling harms consumer welfare is not clear even within a particular theory of harm: the specific facts of the case matters a lot. The economic theories of bundling and tying are far from settled and policymakers need to bear this in mind. ${ }^{142}$

Apart from recognising the certain limitations of the extent that economics can inform legal thinking, the other important and unavoidable debate is on the correct attitude that courts and enforcement authorities should have when faced with antitrust allegations. As shown above, here it is important to be aware of, and where necessary dispel, the (sometimes irrational) assumptions that play a role in the assessment of such allegations. $^{143}$

Consistently with this warning, Hovenkamp argues strongly for a more cautious approach by making the point that: ${ }^{144}$

No firm, not even a monopolist, is a trustee for another firm's economies of scale. To force such a firm to hold a price umbrella over its rivals, selling at above-cost prices in order to protect the rivals' inefficiently small production, would be a blatant example of protecting competitors at the expense of consumers.

This view was shared in the US submission to the OECD Roundtable. ${ }^{145}$

\footnotetext{
142 Walker (n 31).

143 Part C-1 of this paper.

${ }^{144}$ Herbert Hovenkamp, 'Discounts and Exclusions' [2006] Utah Law Review 879.

145 Organisation for Economic Co-operation and Development (OECD), Roundtable on Bundled and Conditional Discounts and Rebates, United States submission, $\mathrm{DAF} / \mathrm{COMP} / \mathrm{WP} 3 / \mathrm{WD}(2008)$ $<$ http://www.justice.gov/atr/public/international/234014.pdf $>$ accessed on 2 July 2012.
} 
On the subject of multi-product rebates, the DOJ in its Section 2 Report, while recognising the theoretical possibility for anticompetitive conduct to come within the discount-allocation safe harbour, particularly where 'bundled discount denies competitors the ability to attain economies of scale', strongly believed that 'the potential chilling effect on legitimate price discounting' was the most important reason to stop further investigation of the conduct that comes within the safe harbour. ${ }^{146}$ This was despite the risk of false negatives posed by the safe harbour and the imperfect nature of the 'hypothetical equally efficient competitor' concept on which the safe harbour was based. ${ }^{147}$ Geradin further adds that, even if there are cases where above cost pricing could lead to foreclosure, such cases would be rare. ${ }^{148}$

Lastly, and more generally speaking, there is something fundamentally unsound about preventing firms from cutting their prices on the grounds that this may eliminate rivals that may force these firms to price even lower: it is completely speculative. Trading current price-cuts for such speculative 'future price-cuts' may not be a good idea as far as antitrust law is concerned. ${ }^{149}$ Hovenkamp has gone even further to argue that 'when a particular form of behaviour is too complex for reliable analysis, then the only defensible antitrust rule is to let the market rather than the courts control... The basic rule should be non-intervention unless the court is confident that it has identified anti-competitive conduct and can apply an effective remedy. ${ }^{, 150}$

\section{The Absence of Empirical Analysis}

The economic literature in this area is still underdeveloped and that there is a lack of empirical evidence on how bundling actually affects competition. And while recent articles have shown that bundled discounts

\footnotetext{
${ }^{146}$ Department of Justice, 'Section 2 Report' (n 1).

${ }^{147}$ OECD, Roundtable (n 145) para 25.

${ }^{148}$ Geradin (n 5).

${ }^{149}$ Einer Elhauge, 'Why Above-Cost Price Cuts To Drive Out Entrants Are Not

Predatory - and the Implications for Defining Costs and Market Power' (2003) 112

Yale Law Journal 681.

${ }^{150}$ Herbert Hovenkamp, The Antitrust Enterprise: Principle and Execution (Harvard University Press 2005) 47.
} 
can, in theory, exclude competitors, the models that they have used are often built on unrealistic assumptions. ${ }^{151}$

Muris and Smith have argued that, demonstrating that anticompetitive harm is theoretically possible in certain specified demand-cost environments, is not sufficient to show that such harm is likely or that any potential for harm would outweigh any demonstrable benefits from the bundling practice. They have further asserted that 'antitrust rules and tests that cannot be administered accurately are often worse than no rules at all. ${ }^{152}$

Kobayashi echoes their view by identifying several characteristics of the currently available economic literature on commodity bundling as (1) focusing on theoretical treatments of bundling and identifying the wide range of reasons why firms might engage in bundling; (2) generally containing restrictive assumptions, e.g. assumptions regarding the existence of monopoly and the nature of rivalry; and (3) generally suppressing the more obvious and ubiquitous reasons for which firms may use bundling. ${ }^{153}$

\section{Error Costs and Trade-Offs: Choosing the Right Analytical Framework}

Ahlborn and Barley have theorised that in designing antitrust polices relating to bundled discounts, the policy makers face two fundamental trade-offs: a trade-off between false positives and false negatives, and a trade-off between error costs on one hand and administrative costs on the other. ${ }^{154}$ It is increasingly recognised that some form of economic welfare (consumer welfare or total welfare) should be the benchmark for competition policy. This means that any legal rules governing discounting practices should 'minimize its enforcement costs, remedy its error costs and its administrative costs. ${ }^{155}$ Indeed, Posner goes as far as saying that

\footnotetext{
${ }^{151}$ Timothy J. Muris and Vernon L. Smith, 'Antitrust and Bundled Discounts: An Experimental Analysis' (2008-09) 75 Antitrust L.J. 399; Areeda and Hovenkamp (n 29).

152 ibid.

${ }^{153}$ Kobayashi, 'The Economics of Loyalty Discounts and Antitrust Law in the United States' (n 47).

${ }^{154}$ Ahlborn and Bailey (n 82) 115.

155 ibid 114.
} 
the goal of legal rules is to minimise the sum of error costs and direct costs. $^{156}$

Detailed discussions on enforcement and administrative costs are beyond the scope of this article. Instead, its main concern is how to design a set of optimal antitrust policies for bundled discounts that can both guard desirable price-cutting activities by the dominant firms and expose those arrangements that pose serious threat to the competitiveness of the market. More specifically, this means aiming to minimise error costs through the construction of appropriate legal rules in the first place.

The factors needed to be taken into account have been summarised as follows: 'the greater the frequency of pro-competitive relative to anticompetitive discounts, the greater the relative frequency of false positives; and the greater the cost of false positives, the more permissible should be the legal rule. 157

However, there are major difficulties in achieving this optimal policy design, which are due to the following three factors: (1) the relatively infrequent case law tackling the specific area of bundled discount, making it difficult to build a reliable record of the frequencies of the two types of error costs; (2) the absence of any unifying theories of harm from the economic literature; and (3) lack of consensus among the judiciary or the central governing bodies in both the US and the EU on the most suitable test that can be deployed to separate the pro-competitive from the anticompetitive types of bundled discounts.

\section{How Different Purposes of Competition Law Regimes Come into Play: a Comparative Perspective}

Recall the central element of the ECJ Michelin II decision, which was 'not all competition on price can be regarded as legitimate. ${ }^{158}$ The court was emphasising the need for multi-product dominant firms to compete on the merits with their competitors and so to grant discounts only if economically justified. In comparison, the Ninth Circuit in Cascade Health Solutions relied on the fact that bundled discounts are a "pervasive

\footnotetext{
${ }^{156}$ Richard A. Posner, Economic Analysis of Law ( $7^{\text {th }}$ edn. Aspen Publishers 2007) 593.

${ }^{157}$ Ahlborn and Bailey (n 82).

${ }^{158}$ Michelin II (n 89) para 97.
} 
practice' employed by both large and small corporations and called for a more lenient approach from the US antitrust regime. ${ }^{159}$

These two cases and their contrasting attitudes on 'price' competition highlight a strong contrast between EU and US treatment of dominant firms or monopolies. I argue that this is because their respective competition law systems were designed to serve different purposes respectively to begin with. What s. 2 of the Sherman Act prohibits is monopolisation. This, as some commentators explain, means that the likelihood that the conduct in question was designed to expand monopoly power could be strongly undermined if the same practice is also used by non-dominant firms. ${ }^{160}$ Article $102 \mathrm{EC}$, on the other hand, has a different structure and regulatory purpose. As Hovenkamp explains, '[it is] less concerned about the creation of dominant positions and more focused on regulating their behaviour once dominance has been achieved.' 161

Thus, while the fact that a practice is pervasive in the economy is a relevant factor in the US, it is not so in the enforcement of art. 82, as dominant firms in the EU are expected to carry greater responsibility in the preservation of the marketplace. Advocate General Kokott's opinion in British Airways highlights this point succinctly: ${ }^{162}$

Within the scope of the application of Article $82 \mathrm{EC}$, a dominant undertaking is subject to certain limitations that do not apply to other undertakings in the same form... [The undertaking in a dominant position] has a particular responsibility to ensure that its conduct does not undermine effective and undistorted competition in the common market. A practice which would be unobjectionable under normal circumstances can be an abuse if applied by an undertaking in a dominant position.

\footnotetext{
${ }^{159}$ Cascade Health Solutions (n 56).

${ }^{160}$ Economides and Lianos (n 33) 22.

${ }^{161}$ Herbert J. Hovenkamp, 'The Legal Periphery of Dominant Firm Conduct' in Abel M. Mateus and Teresa Moreira (eds) Competition Law and Economics: Advances in Competition Policy Enforcement in the EU and North America (Edward Elgar 2010) 238.

${ }^{162}$ British Airways (n 88), Opinion of AG Kokott < http://eurlex.europa.eu/LexUriServ/LexUriServ.do?uri=CELEX:62004CC0095:EN:NOT> accessed on 2 July 2012, para 23.
} 
This is also the reason why in the EU context the fact that non-dominant firms also use the same practice is irrelevant, as the purpose of art. 102 is to impose special responsibilities on dominant undertakings. This would be a totally different case in the US. Additionally, art. 102 reaches significantly lower market shares. I think it suggests that in cases where the undertaking has a dominant position, the scope of art. 102 is broader than the scope of s. 2 of the Sherman Act.

Such differences in the fundamental purpose of the EU and US antitrust regimes will inevitably translate into a differing degree of willingness to risk committing either Type I errors or Type II errors by their enforcement authorities.

\section{H. Conclusion}

In this paper, I carried out a detailed examination on many of the key issues surrounding the antitrust treatment of bundled discounts in the United States and Europe. On the subject of economic justifications for bundled discounting practices, Elhauge argues that pricing that varies together with the buyers' demand, and in turn offers one buyer a greater discount than another, is difficult to justify on efficiency grounds. ${ }^{163}$

This argument highlights the particular challenge that we face: namely, that bundled discounts as a potential form of exclusionary conduct is multidimensional. Economic explanations that can successfully apply to one sub-category of such practices may not necessarily apply to another.

Despite the recent increase in economic literature on the topic of bundled discounts, the theoretical and empirical analyses of such practice as a potentially exclusionary mechanism are 'relatively recent and sparse'. ${ }^{164}$ The judiciary, antitrust scholars and enforcement authorities have so far been unable to agree on a set of coherent principles to guide the design of liability standards in this area. The fact that there is no unifying theory of harm has also contributed greatly to the elusive character of this area of competition law.

${ }^{163}$ Einer Elhauge, United States Antitrust Law and Economics (Foundation Press 2008) 415.

${ }^{164}$ LePage's (n 63), Brief of the United States as Amicus Curiae

<http://www.justice.gov/atr/cases/f203900/203900.htm> accessed on 2 July 2012. 
A common approach adopted by academic scholars in an attempt to overcome this obstacle is to examine bundled discounting practices under frameworks that are somewhat similar to those with which we are more or less already familiar. To this end, some have advocated for a liability standard that draws from both predatory pricing and tying. ${ }^{165}$ In contrast, some prefer to adopt a slightly modified version of either of these two. There are also scholars proposing a unified 'structured rule of reason' test for bundling, tying and loyalty/requirement program. ${ }^{166}$

The problem is that antitrust categories are not always clear cut. It is often possible to fit a case into several specific and distinct categories. Therefore, there is a real danger of the same case being scrutinised under completely different liability standards, thereby creating theoretical confusion and undermining legal certainty, purely because it is put into one antitrust category rather than another.

It is also important to note that antitrust categories are not mere analytical tools, but reflective of the objects and underlying premises of the entire competition law system in which they operate. ${ }^{167}$ Thus, on the most fundamental level, the analysis should be what the antitrust regime as a whole is trying to achieve. Rather than designating a case as a 'bundled discounts', 'tying' or 'exclusive dealing' etc., and trying to apply pre-determined models to cases, a better approach may be to go back to first principles: what is the theory of harm that we seek to rely upon, and what evidence we need to substantiate it.

For now, what I hope this paper has succeeded in showing is that the antitrust treatment of bundled discounts and rebates is an area of competition law that demands substantial on-going conversations between the judiciary, the enforcement authorities and the wider academia as a whole.

\footnotetext{
${ }^{165}$ E.g. Areeda and Hovenkamp (n 29) 251.

${ }^{166}$ Economides and Lianos (n 33).

167 ibid.
} 